\title{
Source assessment of deposited particles in a Slovenian show cave (Postojnska jama): evidence of long-lasting anthropogenic impact
}

\author{
Gregor Muri ${ }^{1 *}$, Aleksandra Jovičić ${ }^{2}$, and Andrej Mihevc ${ }^{3}$ \\ ${ }^{1}$ Slovenian Environment Agency, Vojkova 1b, 1000 Ljubljana, Slovenia \\ 2 School of Environmental Sciences, University of Nova Gorica, Vipavska 13, 5000 Nova Gorica, Slovenia \\ ${ }^{3}$ Karst Research Institute ZRC SAZU, Titov trg 2, 6230 Postojna, Slovenia
}

Abstract: Postojnska jama (Postojna Cave) is one of the most famous karst caves in the world and has been a well-known tourist attraction for nearly 200 years. It is particularly famous for its unique double-track railway. Eight heavy metals - aluminium (Al), chromium (Cr), copper $(\mathrm{Cu})$, iron $(\mathrm{Fe})$, lead $(\mathrm{Pb})$, manganese $(\mathrm{Mn})$, strontium $(\mathrm{Sr})$, and zinc $(\mathrm{Zn})$ - were determined in dust deposits by ICP-MS in order to assess sources of deposited particles on the cave walls. The samples were collected along the main passage in the cave, at different horizontal and vertical levels, in order to test horizontal homogeneity and study vertical distribution of the particles. It seems that the railway is an important anthropogenic source of particles, reflected in increased concentrations of $\mathrm{Cu}, \mathrm{Pb}$, and $\mathrm{Zn}$, as well as of $\mathrm{Fe}$ and $\mathrm{Mn}$ in dust deposits at individual sampling sites. The maximum concentrations of $\mathrm{Cu}\left(217 \mu \mathrm{g} \mathrm{g}^{-1}\right), \mathrm{Pb}$ $\left(4,940 \mu \mathrm{g} \mathrm{g}^{-1}\right)$, and $\mathrm{Zn}\left(1,060 \mu \mathrm{g} \mathrm{g}^{-1}\right)$ considerably exceeded their natural abundance and were explained by anthropogenic impact. The three heavy metals are markers for vehicles, engine oil and brake wear. On the other hand, mixed sources could prevail for Fe and $\mathrm{Mn}$. The maximum concentrations of $\mathrm{Fe}\left(85,900 \mu \mathrm{g} \mathrm{g}^{-1}\right)$ and $\mathrm{Mn}\left(682 \mu \mathrm{g} \mathrm{g}^{-1}\right)$ in dust deposits were similar to the concentrations determined in fragments of the railway tracks $\left(97,100 \mu \mathrm{g} \mathrm{g}^{-1}\right.$ for $\mathrm{Fe}$ and $821 \mathrm{\mu g} \mathrm{g}^{-1}$ for $\mathrm{Mn}$ ) and were explained by track wear and/or corrosion. In most other parts of the cave, Fe and Mn concentrations were, however, below the concentration of their natural abundance. $\mathrm{Al}, \mathrm{Sr}$, and $\mathrm{Cr}$ seem to be predominantly of natural origin. They generally exhibited concentrations lower than their natural abundance.

Keywords: dust; heavy metals; source apportionment; tourism; Postojna Cave

Received 21 March 2013; Revised 7 July 2013; Accepted 15 July 2013

Citation: Muri G., Jovičić A. and Mihevc A., 2013. Source assessment of deposited particles in a Slovenian show cave (Postojnska jama): evidence of long-lasting anthropogenic impact. International Journal of Speleology, 42 (3), 225-233. Tampa, FL (USA) ISSN 0392-6672 http://dx.doi.org/10.5038/1827-806X.42.3.6

\section{INTRODUCTION}

Caves are part of a larger karst ecosystem. They have unique physical and biological characteristics and are dynamic ecosystems of landforms, life, energy, water, gases, soils and bedrock. In general, caves are highly sensitive and vulnerable to disruption/degradation. Since all caves are subject to natural and human-induced disturbance, they should be carefully managed in all of the abovementioned fields in order to prevent any degradation of these ecosystems (Watson et al., 1997; Russell \& MacLean, 2008; White \& Culver, 2012). Many caves also represent important resources for tourism. The impact of tourism on a cave is much more evident in a low-energy environment where any human presence, such as visitors to the cave, may be reflected in considerable changes to the ecosystem no matter how carefully the cave is managed. A high-energy environment (e.g. a cave with a large throughput of water), on the other hand, is generally much less sensitive to any changes (Watson et al., 1997; de Freitas, 2010). Anthropogenic impact on caves has been studied from many perspectives including studies of heavy metals in different matrices (e.g. Gutiérrez et al., 2004; Dongarra et al., 2010; Cuculić et al., 2011; Zhou et al., 2011), but such studies are relatively rare. In general, various sources may contribute harmful substances such as heavy metals to an environment. A proper identification of sources that release these substances would not just provide a means for their most effective control but also allow prioritisation of the most significant substances and/or sources that would ultimately 
lead to reduced levels of harmful substances in the environment (Bruinen de Bruin et al., 2006).

Postojnska jama (Postojna Cave) is one of the most famous karst caves in the world. It is the cave with the greatest diversity of endemic cave fauna, one of the oldest and largest show caves in the world, and the largest managed cave in the Dinaric karst (Gams, 2003). As such, it has received much scientific attention across various fields. Physical (Šebela \& Turk, 2011), chemical (Vokal et al., 1999; Zupančič et al., 2011), and biological parameters (Sket, 2003; Mulec et al., 2012), as well as radioactivity (Gregorič et al., 2011), have all been included in past research activity. Postojnska jama has also been a well-known tourist attraction for nearly 200 years. Development of the cave for tourism began in as early as 1818 and the number of visitors then grew consistently. The cave is particularly famous for its railway; it is the only cave in the world with a double-track railway. Petrolpowered locomotives began operating on a single track in 1924. Between 1964 and 1968 the single track was upgraded to a circular, double-track railway covering $3.7 \mathrm{~km}$ of the $5 \mathrm{~km}$ section of the cave that is open to visitors. Along with the reconstruction of the tracks in the 1960s, battery-powered locomotives were introduced (Čuk, 2003). In the following years, an enormous increase of visitors was observed. The peak period of cave visits was recorded between 1970 and 1990. In this period, more than 16 million visitors from all over the world came to see the cave, including as many as $~ 942,000$ visitors in the peak year of 1985 and up to $\sim 12,000$ visitors per day (on 8 July 1978). In recent years, the number of visitors has stabilised at approximately a half a million tourists per year (Hrovatin, 2006).

The goal of this paper is to assess sources of deposited particles on the walls in the cave system of Postojnska jama and to examine whether the abundance and composition of the particles has been affected by natural processes or anthropogenic impact due to the cave's tourist facilities. A railway has been operating in the cave for the last 89 years, and this may represent a substantial environmental burden on the cave. The cave receives massive number of visitors resulting in frequent train rides into and out of the cave. Deposited particles were scraped from the walls in the main passage of the cave system and chemically characterised. Concentrations of eight heavy metals - aluminium (Al), chromium (Cr), copper $(\mathrm{Cu})$, iron $(\mathrm{Fe})$, lead $(\mathrm{Pb})$, manganese $(\mathrm{Mn})$, strontium (Sr), and zinc $(\mathrm{Zn})$ - were determined in the wall deposits, sprinkling sand and parts of the railway track. The mineral composition of the fresh sprinkling sand was also identified. Finally, relations among the parameters and the sampling sites were studied.

\section{MATERIALS AND METHODS}

\section{Site description}

Postojnska jama $\left(45^{\circ} 46^{\prime} 58^{\prime \prime} \mathrm{N}, 14^{\circ} 12^{\prime} 13^{\prime \prime} \mathrm{E}\right)$ is over $20 \mathrm{~km}$ long and is situated under the Postojna karst plateau. The cave is developed in upper Cretaceous limestone and limestone with chert lenses and was formed by the sinking Pivka river, which still flows through passages of the lower level of the cave. The passages of the upper level of the cave are no longer within the flood zone of the river and are mostly covered with calcite flowstone. The cave has several known entrances at different elevations, but there are also other less-known accesses from the surface, e.g., small openings and fissures (Gabrovšek \& Mihevc, 2009; White \& Culver, 2012).

As a result of the several entrances and openings at different elevations and differences in temperature between the cave and the ambient air, strong air currents occur in the cave. Air temperature in a cave depends on the temperature of the rock, which in karst areas is usually close to the mean annual temperature of the surface (Badino, 1995). In the warm part of the year, when the air in a cave is colder than the outside air, the cave air moves towards the lower entrance of the cave and out. Warmer ambient air enters the cave through the upper openings on the plateau, cooling down as it enters, which results in an increase of relative humidity and subsequent condensation of water vapour on the cave walls, so that the walls get wet. This process also affects the adhesion of particles to the cave wall surface, since wetter surface increases hydraulic retention of particles (Dredge et al., 2013). In winter, the air circulation is reversed. The warmer cave air exits through upper openings and draws colder ambient air in through the lower entrance. The ambient air warms in contact with the cave walls, resulting in a decrease of relative humidity and causing the walls to dry. The velocity of the air current through the main entrance of the cave, which has a profile of $30 \mathrm{~m}^{2}$, can reach $1.5 \mathrm{~m} \mathrm{~s}^{-1}$ in winter, desiccating the floor and walls of the main passage for a distance of about $1.5 \mathrm{~km}$ in the direction of Velika Gora (Fig. 1). Furthermore, the air current is likely to be responsible for the transport of dust particles in the cave in the winter (e.g. Pashchenko et al., 1993; Christoforou et al., 1996; Kertész et al., 1999; Gabrovšek \& Mihevc, 2009; Dredge et al., 2013). Clearly visible dust deposits can generally be found only in the main passage (called 'Stara Jama'; Fig. 1, Supplementary Material 1) stretching between the main entrance and Velika Gora. The passage is approximately $10 \mathrm{~m}$ wide and $10 \mathrm{~m}$ high, with some wider segments. In contrast, in narrow side passages where there is no air circulation no desiccation is observed, the temperature is higher and there are practically no dust deposits (Gams, 2003; Gabrovšek $\&$ Mihevc, 2009; Supplementary Material 2).

\section{Sampling}

In February 2011, fourteen samples were collected from the walls at five locations in the main passage of the cave (Fig. 1). All sampling sites were located along the railway tracks, and the location of sample 1 was closest to the entrance. This sample was collected in the black part of the cave (referred to as the "black section" hereafter) approximately 1 metre above the tracks. The sample was coded as 1.1 in which the first figure in the sampling site code represents the sampling location and the second the sampling height. 


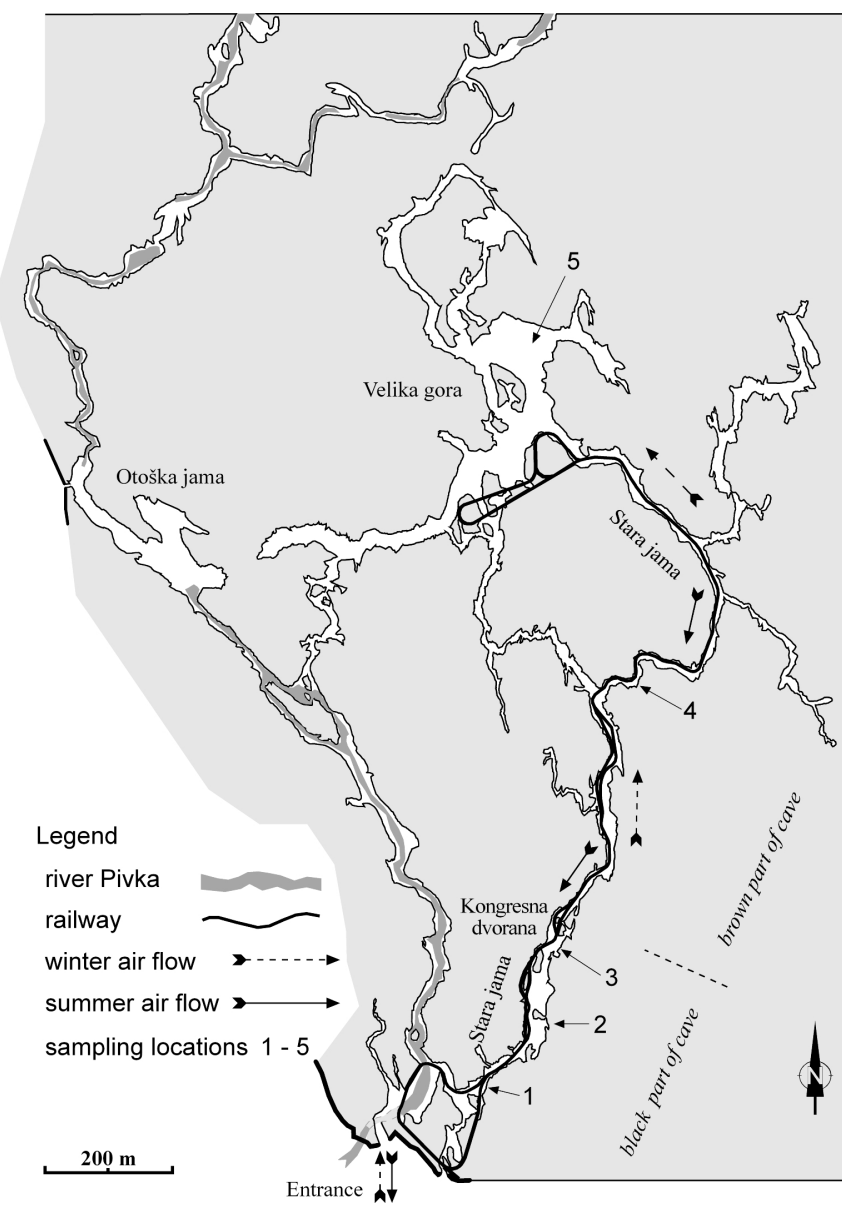

Fig. 1. The sampling locations: 1) the black section, 2) vertical samples outside Kongresna Dvorana ('Congress Hall'), 3) samples of lower and upper horizontal levels in Kongresna Dvorana, 4) the brown section,

5) vertical samples in Velika Gora, as well as air flows and the course of the railway through the cave system of Postojnska jama.

Three samples from location 2 were collected at different elevations $(\sim 1,10$, and 20 metres above the tracks) in order to study the vertical distribution of dust deposits. These samples were coded as 2.1, 2.10, and 2.20, respectively. Six samples were collected in Kongresna Dvorana ('Congress Hall'; location 3 ) in order to study the horizontal distribution of dust deposits. Samples 3.1A, 3.1B, and 3.1C were all collected at approximately 1 metre above the tracks, but at different places in the chamber. A character has been added to the sampling site code to distinguish between the samples. A second group of samples (3.3A, 3.3B, and 3.3C) at this location was collected on a horizontal level approximately 3 metres above the tracks. The sample at location 4 was collected in the brown part of the cave (referred to as the "brown section" hereafter) approximately 1 metre above the tracks and coded as 4.1. The last three samples $(5.1,5.20$, and 5.40) were taken in the interior of the cave, i.e., Velika Gora (location 5) where the railway ends, again at different elevations ( 1, 20, and 40 metres above the tracks, respectively). At each sampling site, a sample was collected for the purpose of chemical characterisation. In contrast, samples for gravimetric analysis were only obtained at selected sampling sites where a sufficiently large flat area was found on the cave walls. No vertical or horizontal distributions of the particles were studied in this case.
The cave walls at the sampling sites are covered with a thin layer of deposited particles. These particles were gently scraped away using a brush with nylon bristles, in order to prevent bedrock scrapings from contaminating the samples. The samples used for gravimetric analysis were quantitatively scraped away from a unit area $(20 \times 20 \mathrm{~cm})$. All samples were collected into a polyethylene Petri dish. Sampling utensils and containers were rinsed with Milli-Q water and diluted nitric acid $(1: 2 \mathrm{v} / \mathrm{v})$ in the laboratory and wrapped in plastic bags to prevent contamination. Samples were stored refrigerated at $4^{\circ} \mathrm{C}$ until further analysis.

\section{Chemical and data analysis}

Heavy metals in the deposited particles were determined according to the EN 14902 (2005) and EN ISO 17294-2 (2005) standards. Samples were first oven-dried for $24 \mathrm{~h}$ at $105^{\circ} \mathrm{C}$. Subsequently, approximately $100-120 \mathrm{mg}$ of dry sample was weighed into a high pressure Teflon vessel. A mixture of nitric acid $(65 \% \mathrm{w} / \mathrm{w}$, Suprapure) and hydrogen peroxide $(30 \% \mathrm{w} / \mathrm{w}$, Suprapure $)$ in the ratio 4:1 was added into each vessel. The vessels were closed and the samples digested in a microwave oven (Milestone, Ethos 1). The microwave system provided $1200 \mathrm{~W}$ of power, ensuring complete digestion at a temperature of $220^{\circ} \mathrm{C}$ (for 25 minutes). After cooling, the digestate was transferred into a 50 $\mathrm{ml}$ volumetric flask, a mixture of internal standards (scandium, germanium, rhodium and gadolinium) was added and the digestate diluted with Milli-Q water to the mark. Each sample was prepared in five replicates. Additionally, blank and control samples were performed with each set of seven samples for quality control.

Concentrations of selected heavy metals were determined by ICP-MS (Perkin Elmer, Sciex Elan 6100) equipped with a Gem-Tip cross-flow nebulizer and a Scott-type spray chamber. The following $\mathrm{m} / \mathrm{z}$ were selected for measurements: ${ }^{27} \mathrm{Al},{ }^{53} \mathrm{Cr},{ }^{55} \mathrm{Mn}$, ${ }^{57} \mathrm{Fe},{ }^{63} \mathrm{Cu},{ }^{66} \mathrm{Zn},{ }^{88} \mathrm{Sr}$, and ${ }^{208} \mathrm{~Pb}$. Each digestate was measured in two replicates. The limits of detection

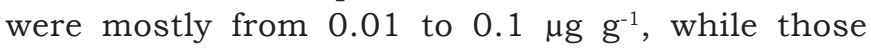
of $\mathrm{Al}, \mathrm{Fe}$ and $\mathrm{Zn}$ were a bit higher $\left(0.5-2 \mu \mathrm{g} \mathrm{g}^{-1}\right)$. Instrumental precision of the measurements was up to $5 \%$ and a certified reference material (NIST 1648a) was used to control the trueness of the analytical procedure.

The mineral composition of the fresh sprinkling sand was characterised by X-ray diffractometer (Philips, PW 1820) carried out on unoriented powder mounts. Qualitative estimation was based on peak intensity measurement of X-ray patterns ( $\mathrm{Cu} \mathrm{Ka} \mathrm{/} \mathrm{Ni}$ $40 \mathrm{kV}, 30 \mathrm{~mA}$ ) using the X'Pert HighScore software program.

Basic descriptive statistics were used to describe the data variability. Average and standard deviation was calculated for each parameter and sampling location. In addition, the strength of relation between heavy metals across the sampling sites was ascertained using the Pearson correlation coefficient. 
Table 1. Concentrations of heavy metals in the deposited particles along the main passage in Postojnska jama. Each sampling site code contains two figures and an optional character; the first figure (in bold) represents the sampling location (legend as in Fig. 1), the second one is its sampling height, and the character represents different samples from the same horizontal level. "Vertical" and "horizontal" designate locations where vertical and horizontal distributions of the particles were studied. All concentrations are in $\mu \mathrm{g} \mathrm{g}^{-1}$.

\begin{tabular}{|c|c|c|c|c|c|c|c|c|c|c|c|c|c|c|}
\hline & \multirow[t]{2}{*}{1.1} & 2.1 & 2.10 & 2.20 & $3.1 \mathrm{~A}$ & $3.1 \mathrm{~B}$ & $3.1 \mathrm{C}$ & $3.3 \mathrm{~A}$ & $3.3 \mathrm{~B}$ & $3.3 \mathrm{C}$ & \multirow[t]{2}{*}{4.1} & \multirow{2}{*}{\multicolumn{3}{|c|}{$\begin{array}{c}5.20 \\
\text { Vertical }\end{array}$}} \\
\hline & & \multicolumn{3}{|c|}{ Vertical } & \multicolumn{3}{|c|}{ Horizontal - lower level } & \multicolumn{3}{|c|}{ Horizontal - upper level } & & & & \\
\hline Al & 1,200 & 4,110 & 32,900 & 8,770 & 10,500 & 4,490 & 4,130 & 6,590 & 6,740 & 3,020 & 3,100 & 4,950 & 3,650 & 9,120 \\
\hline $\mathrm{Cr}$ & 7.76 & 26.7 & 63.5 & 22.4 & 24.5 & 9.69 & 27.0 & 24.7 & 76.8 & 15.8 & 68.8 & 62.5 & 20.5 & 27.0 \\
\hline $\mathrm{Cu}$ & 54.8 & 57.2 & 69.7 & 207 & 23.5 & 26.2 & 53.7 & 69.6 & 176 & 217 & 178 & 88.2 & 42.1 & 32.4 \\
\hline $\mathrm{Fe}$ & 5,800 & 39,100 & 28,500 & 73,700 & 9,650 & 8,020 & 8,400 & 17,000 & 546 & 10,900 & 85,900 & 13,600 & 6,050 & 11,200 \\
\hline Mn & 46.0 & 282 & 682 & 332 & 272 & 117 & 162 & 265 & 288 & 117 & 644 & 202 & 134 & 233 \\
\hline $\mathrm{Pb}$ & 436 & 309 & 302 & 400 & 80.2 & 1,950 & 571 & 424 & 839 & 4,940 & 500 & 2,150 & 205 & 156 \\
\hline $\mathrm{Sr}$ & 59.7 & 151 & 132 & 164 & 79.1 & 189 & 162 & 567 & 1,300 & 235 & 134 & 127 & 61.8 & 124 \\
\hline $\mathrm{Zn}$ & 108 & 134 & 154 & 476 & 114 & 70.7 & 190 & 186 & 723 & 1,060 & 342 & 421 & 93.3 & 97.5 \\
\hline
\end{tabular}

\section{RESULTS}

The concentrations of heavy metals in the deposited particles are presented in Table 1 and Fig. 2. Fe was the most abundant heavy metal at eleven out of fourteen sampling sites, and it exhibited a wide range of concentrations (546-85,900 $\left.\mathrm{ug} \mathrm{g}^{-1}\right)$, with the highest concentration observed at sampling site 4.1. Al was the most abundant heavy metal at the remaining three sampling sites, while at most of the other sampling sites it was second highest in abundance. Its concentration ranged from 1,200 to $32,900 \mu \mathrm{g}$ $\mathrm{g}^{-1}$ (at sampling site 2.10 ). All other measured heavy metals were considerably less abundant. Only $\mathrm{Pb}, \mathrm{Sr}$, and $\mathrm{Zn}$ exceeded 1,000 $\mu \mathrm{g} \mathrm{g}^{-1}$. The highest concentration of $\mathrm{Pb}$ was $4,940 \mu \mathrm{g} \mathrm{g}^{-1}$ at sampling site $3.3 \mathrm{C}$ (and approximately 2,000 $\mu \mathrm{g} \mathrm{g}^{-1}$ at two other

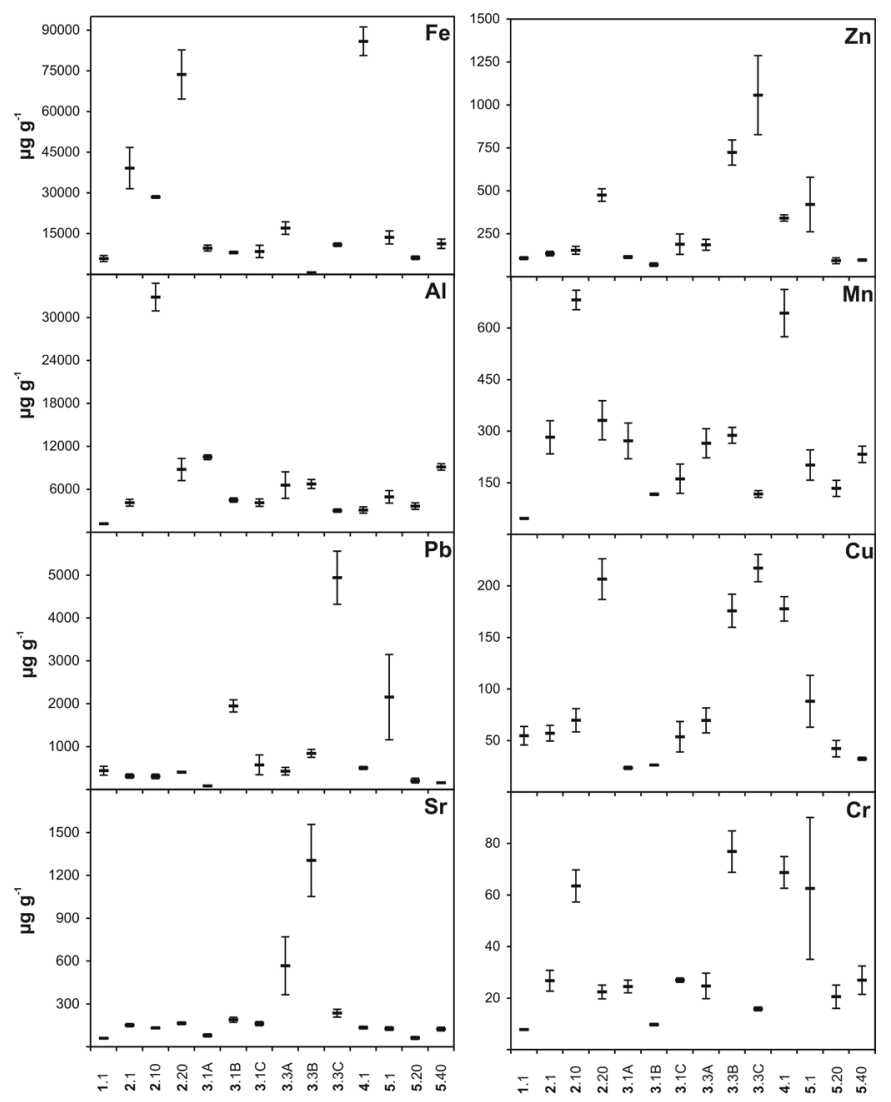

Fig. 2. Distribution of heavy metals along the main passage in Postojnska jama (average value and one standard deviation of the data are presented). Each sampling site code contains two figures; the first one (in bold) represents the sampling location (legend as in Fig. 1) and the second one is its sampling height. The sampling site codes containing characters represent different samples from the same horizontal level. sampling sites), while that of $\mathrm{Sr}$ was $1,300 \mu \mathrm{g} \mathrm{g}^{-1}$ at sampling site $3.3 \mathrm{~B}$ and that of $\mathrm{Zn}$ was $1,060 \mu \mathrm{g} \mathrm{g}^{-1}$ at sampling site 3.3C. At all other sampling sites, the concentrations of $\mathrm{Pb}$ amounted to a few hundred

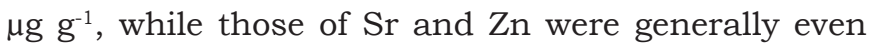
lower. The concentrations of Mn were all below 1,000 $\mu \mathrm{g} \mathrm{g}^{-1}$, while the concentrations of $\mathrm{Cr}$ and $\mathrm{Cu}$ did not exceed $200 \mu \mathrm{g} \mathrm{g}^{-1}$.

The concentrations of heavy metals in the fresh sand that is used for sprinkling the railway tracks are shown in Fig. 3. Fe exhibited the highest concentration $\left(2,340 \mu \mathrm{g} \mathrm{g}^{-1}\right)$, followed by Sr and Al (438 and $298 \mu \mathrm{g} \mathrm{g}^{-1}$, respectively). All other heavy metals were considerably less abundant, with concentrations lower than $18 \mu \mathrm{g} \mathrm{g}^{-1}$. According to X-ray diffractometry, the fresh sprinkling sand is composed solely of calcite (Fig. 4). On the other hand, $\mathrm{Fe}, \mathrm{Al}$ and $\mathrm{Mn}$ concentrations increased markedly in sand collected beside the railway tracks. Their concentrations amounted to 4,170, 578 and 46 $\mu \mathrm{g} \mathrm{g}^{-1}$, respectively.

Fragments of the railway tracks were also analysed. Their main heavy metal constituents were $\mathrm{Fe}(97,100 \mu \mathrm{g}$ $\left.\mathrm{g}^{-1}\right), \mathrm{Mn}\left(821 \mu \mathrm{g} \mathrm{g}^{-1}\right), \mathrm{Al}\left(383 \mu \mathrm{g} \mathrm{g}^{-1}\right)$ and $\mathrm{Cr}\left(276 \mu \mathrm{g} \mathrm{g}^{-1}\right)$.

The mass of deposited particles per unit area was highest in the black section (sampling site 1.1), amounting to $443 \mathrm{~g} \mathrm{~m}^{-2}$ (Fig. 5). In Kongresna Dvorana, the mass dropped to $211 \mathrm{~g} \mathrm{~m}^{-2}$ (sampling site 3.3B) and decreased even further in the deeper parts of the cave (sampling sites 4.1 and 5.1) ranging from 12 to $24 \mathrm{~g} \mathrm{~m}^{-2}$.

Pearson correlation coefficients between the measured parameters are presented in Table 2. The strongest correlation was observed between $\mathrm{Cu}$ and $\mathrm{Zn}$ (0.87), followed by $\mathrm{Pb}$ and $\mathrm{Zn}$ (0.74). The two correlations were significant at $\mathrm{p}<0.05$. A relatively high and significant correlation was also observed between $\mathrm{Mn}$ and $\mathrm{Al}, \mathrm{Mn}$ and $\mathrm{Cr}$, and $\mathrm{Mn}$ and $\mathrm{Fe}$ ranging from 0.66 to 0.69 . All other correlations were not significant at $\mathrm{p}<0.05$.

\section{DISCUSSION}

\section{Variability of the data}

The concentrations of heavy metals in the deposited particles varied considerably throughout the cave (Table 1, Fig. 2). Deposits from all sampling sites were quite homogeneous. Repeatability mostly ranged from 5 to $15 \%$, based on replicate analyses of the same deposit. Marked changes in concentration were observed at sampling sites where the vertical 


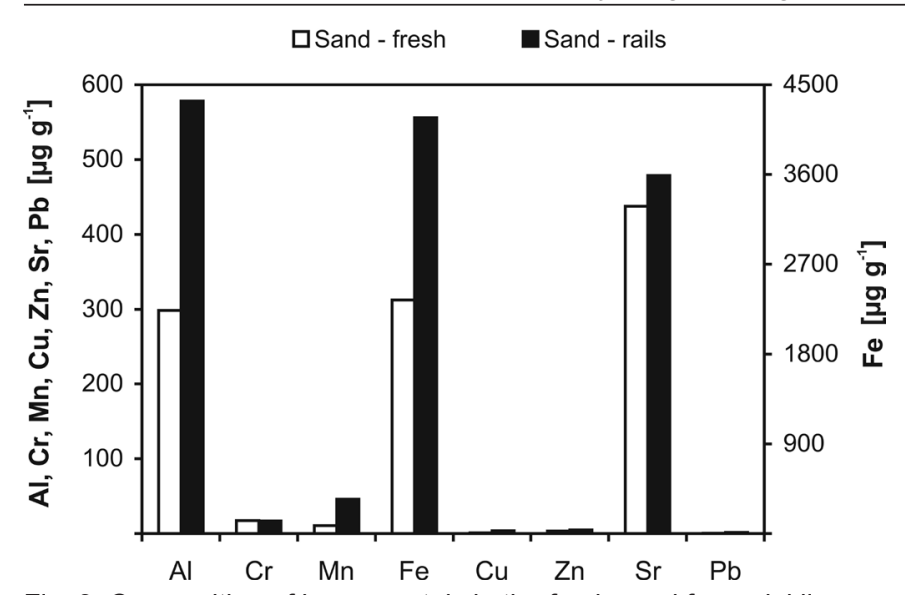

Fig. 3. Composition of heavy metals in the fresh sand for sprinkling and the sand collected beside the railway tracks.

distribution of heavy metals was studied, e.g., sampling sites 2.1, 2.10, 2.20, and 5.1, 5.20, and 5.40. At sampling sites 2.1, 2.10, and 2.20, concentrations were generally higher at higher levels, while maximum concentrations were observed at either sampling site 2.10 or 2.20 . In contrast, $\mathrm{Pb}$ and $\mathrm{Sr}$ showed almost no vertical change in concentration. The opposite was observed at sampling sites 5.1, 5.20, and 5.40 where most parameters exhibited higher concentrations at lower levels. Sr again showed almost no vertical change in concentration. Samples collected from the same horizontal level, e.g. sampling sites 3.1A, 3.1B, 3.1C, and 3.3A, 3.3B, 3.3C mostly showed some degree of heterogeneity. Sampling sites 3.1A, 3.1B, and $3.1 \mathrm{C}$ presented relatively similar distributions of $\mathrm{Fe}, \mathrm{Sr}$, and $\mathrm{Zn}$, suggesting homogeneity of the samples, but the distributions of $\mathrm{Al}, \mathrm{Cr}, \mathrm{Mn}$, and $\mathrm{Pb}$ differed noticeably between the samples, suggesting a reverse relationship. Even greater variations in concentrations were observed at a higher horizontal level (sampling sites 3.3A, 3.3B, and 3.3C). Faimon et al. (2011) demonstrated the relationship between particle size and chemistry; the varying particle sizes and subsequent size controlled distribution effects could explain variations in concentration among the sampling sites in the cave system of Postojnska jama. Nevertheless, we believe that the varying distributions of heavy metals more likely indicate that different sources of particles could be present in the cave. Dust deposited on the walls and floors of the cave has a characteristic colour. For example, between the entrance and the chamber of Kongresna Dvorana, dust deposits are black. Deeper in the cave (from Kongresna Dvorana towards Velika Gora), brown-coloured dust deposits prevail, supporting our supposition of the presence of different sources of particles in the cave.

\section{Source assessment of dust deposits}

\section{The black section}

In the black section (sampling point 1.1), which is situated approximately $500 \mathrm{~m}$ from the entrance (Fig. 1) and thus is the most susceptible to outer factors, very low concentrations of all heavy metals were observed (Table 1, Fig. 2). The overall lowest concentrations of $\mathrm{Al}, \mathrm{Cr}, \mathrm{Mn}$ and $\mathrm{Sr}$ were observed in this part of the cave. In contrast, the highest mass of deposited particles per unit area was observed in this part of the cave (Fig. 5). These deposits were studied in detail by Zupančič et al. (2011). They found that concentrations of $\mathrm{Fe}$ and $\mathrm{Mn}$ oxides were lower than 2-3\%, equalling 20,000-30,000 $\mu \mathrm{g} \mathrm{g} \mathrm{g}^{-1}$, and concluded that the source of these deposits was not the two oxides that would explain black colouring of the particles. Their conclusion is also supported by our data. We determined quite low Fe and $\mathrm{Mn}$ concentrations in deposited particles at this

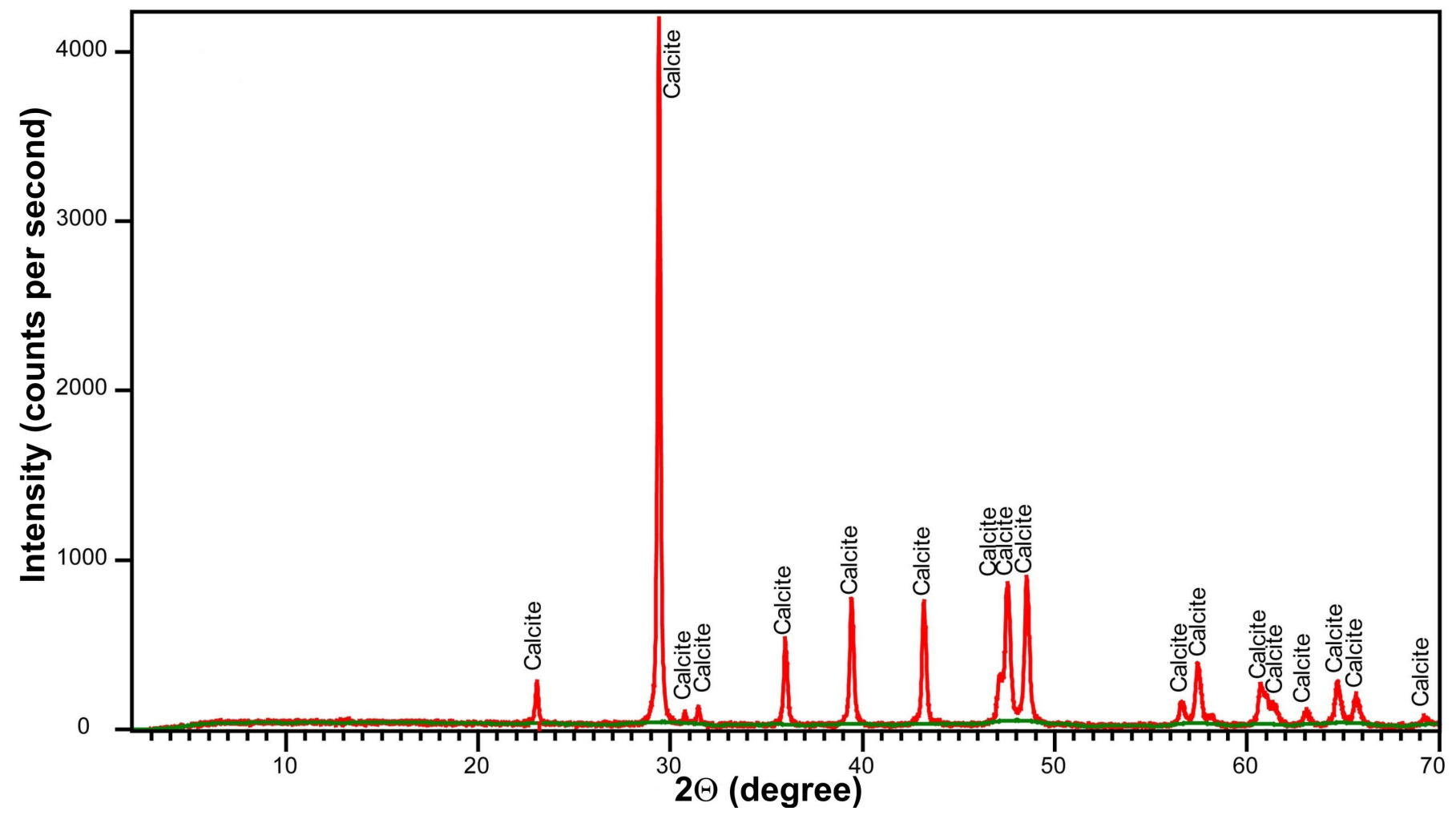

Fig. 4. X-ray power diffraction of the fresh sprinkling sand. 


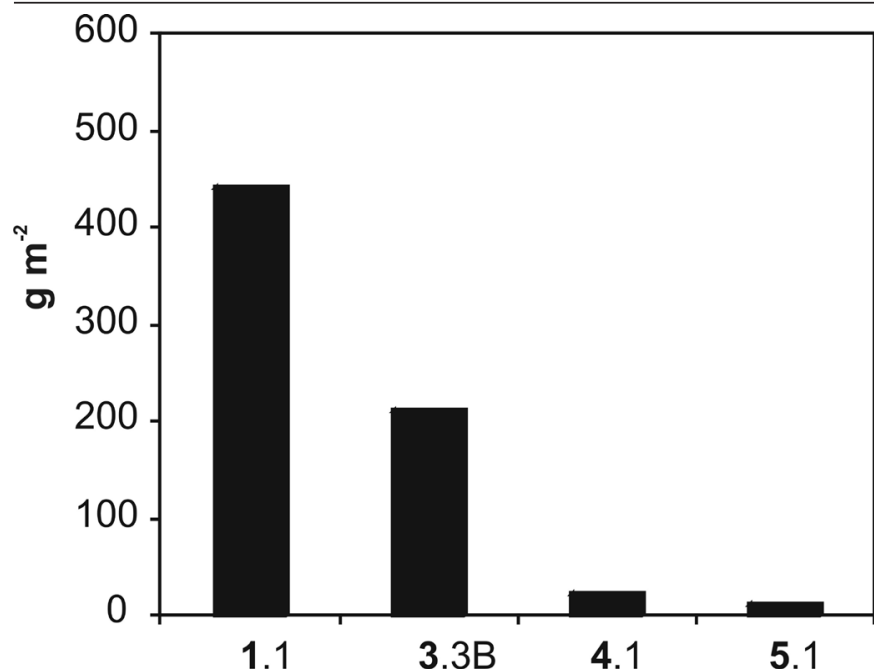

Fig. 5. Mass of deposited particles per unit area along the main passage in Postojnska jama (sampling site legend as in Fig. 2).

sampling site (Table1, Fig. 2). In addition, Zupančič et al. (2011) found that black deposits contained a high content of $\mathrm{C}$. Lack of a significant amount of any other element except $\mathrm{O}$ and some Ca suggested to the authors that black deposits are mainly composed of carbonaceous particles originating from the explosion of gasoline in 1944. During a fuel explosion and a fire, a large quantity of black carbon particles is emitted into the space (Goldberg, 1985). The fuel explosion thus explains the high mass of deposited particles per unit area that was observed in the black section and is between two and thirty-six times higher than in other parts of the cave (Fig. 5). On the other hand, large amounts of carbonaceous particles released in the fuel explosion would also "dilute" other particles, thus explaining the low concentrations of all heavy metals observed in this part of the cave.

It has been shown that in the part of a cave that is close to its entrance, the cave temperature is still influenced by seasonal variations (Leutscher \& Jeannin, 2004). In the black section, temperature variations are thus much lower than at the entrance but still higher than in the interior of the cave, where the temperature usually varies within one degree Celsius (Šebela \& Turk, 2011). The ambient air that enters the cave during the winter period and flows along the main passage (Gams, 2003; Gabrovšek \& Mihevc, 2009) thus has a potential to impact on the cave (Christoforou et al., 1996). Since the ambient air usually contains particulate matter that is polluted with various heavy metals (e.g. Dongarra et al., 2010), it could be expected that this air might influence/alter the composition of heavy metals in Postojnska jama. It seems, however, that this factor is not so important, since the observed concentrations of all heavy metals in the black section were so low. In addition, if particles from the ambient air had been the major source of particles deposited on the walls, then the concentrations of heavy metals should have decreased toward the inner parts of the cave in accordance with the decreasing concentration of particles in the air. This is not the case, and therefore we believe that other factors exist and/or are more important.

\section{The railway}

$\mathrm{Zn}$ and $\mathrm{Cu}$ exhibited the highest correlation among all parameters, while the correlation between $\mathrm{Zn}$ and $\mathrm{Pb}$ was only slightly lower (Table 2). The highest concentrations of all three parameters were observed in the upper part of Kongresna Dvorana (sampling site 3.3C; Table 1, Fig. 2). Although the correlation between $\mathrm{Cu}$ and $\mathrm{Pb}$ was only significant at $\mathrm{p}<0.1$ (0.46), we may conclude that the distribution of the three heavy metals was quite similar throughout the cave, suggesting that they may have the same origin. $\mathrm{Cu}, \mathrm{Pb}$, and $\mathrm{Zn}$ can be naturally found together in minerals, but their abundance is low (Hester \& Harrison, 1997). The common concentration of $\mathrm{Zn}$ in the Earth's crust is around $75 \mu \mathrm{g} \mathrm{g}^{-1}$, with that of $\mathrm{Cu}$ around $50 \mu \mathrm{g} \mathrm{g}^{-1}$ and that of $\mathrm{Pb}$ around $14 \mu \mathrm{g} \mathrm{g}^{-1}$ (Emsley, 2001). The concentration ranges observed in Postojnska jama were clearly higher, suggesting that these three heavy metals could be mostly of anthropogenic origin. These heavy metals have been identified as markers of vehicles, engine oil and brake wear (Bruinen de Bruin et al., 2006), thus indicating that the railway probably has an impact on the cave. On the other hand, the highest concentrations of $\mathrm{Cu}, \mathrm{Pb}$ and $\mathrm{Zn}$ were observed in Kongresna Dvorana, where human presence is evident. This hall is frequently used for the many social events that are held in the cave.

Source assessment for $\mathrm{Fe}$ and $\mathrm{Mn}$ is not as straightforward as for $\mathrm{Cu}, \mathrm{Pb}$ and $\mathrm{Zn}$. Natural abundances of $\mathrm{Fe}$ and $\mathrm{Mn}$ reach up to 41,000 and 1,000 $\mu \mathrm{g} \mathrm{g}^{-1}$, respectively (Emsley, 2001). The concentrations observed in Postojnska jama were mostly considerably lower (Table1, Fig. 2). Only in the brown section (sampling site 4.1) and outside Kongresna Dvorana (sampling sites 2.1, 2.10, and 2.20) did Fe exceed its natural abundance, by a factor of approximately 2, while Mn was roughly three times higher than in other parts of the cave. Railway tracks are typically made of ordinary steel consisting mainly of iron, but in many alloys manganese is also added (Askeland et al., 2011). Since Fe and Mn are the major heavy metal constituents of the railway tracks in Postojnska jama, enriched $\mathrm{Fe}$ and $\mathrm{Mn}$ concentrations in the sand collected beside the railway tracks (Fig. 3; also see the discussion below) indicate that the railway tracks wear out and/or corrode slowly. It is likely that fine particles containing $\mathrm{Fe}$ and $\mathrm{Mn}$ are formed in these processes. In accordance with substantial air currents that have been observed in the fairly narrow main passage along the railway tracks in winter (Gabrovšek \& Mihevc, 2009), the

Table 2. Pearson correlation matrix for measured parameters in deposited particles.

\begin{tabular}{ccccccccc}
\hline & $\mathrm{Al}$ & $\mathrm{Cr}$ & $\mathrm{Cu}$ & $\mathrm{Fe}$ & $\mathrm{Mn}$ & $\mathrm{Pb}$ & $\mathrm{Sr}$ & $\mathrm{Zn}$ \\
\hline $\mathrm{Al}$ & 1.00 & & & & & & & \\
$\mathrm{Cr}$ & 0.37 & 1.00 & & & & & & \\
$\mathrm{Cu}$ & -0.12 & 0.34 & 1.00 & & & & & \\
$\mathrm{Fe}$ & 0.07 & 0.26 & 0.50 & 1.00 & & & & \\
$\mathrm{Mn}$ & $\mathbf{0 . 6 6}$ & $\mathbf{0 . 6 9}$ & 0.26 & $\mathbf{0 . 6 6}$ & 1.00 & & & \\
$\mathrm{~Pb}$ & -0.25 & -0.12 & 0.46 & -0.20 & -0.33 & 1.00 & & \\
$\mathrm{Sr}$ & -0.04 & 0.46 & 0.37 & -0.23 & 0.03 & 0.04 & 1.00 & \\
$\mathrm{Zn}$ & -0.17 & 0.26 & $\mathbf{0 . 8 7}$ & 0.06 & -0.04 & $\mathbf{0 . 7 4}$ & 0.45 & 1.00 \\
\hline
\end{tabular}

Correlation coefficients significant at $p<0.05$ are marked in bold. 
finer and lighter fraction of the particles could easily be transported away. If we presume that only these fine particles are transported along the cave away from the railway tracks, the rather high Fe and $\mathrm{Mn}$ concentrations in the deposited particles in the brown section and outside Kongresna Dvorana would be explained. This supposition is further supported by our data. The maximum concentrations of $\mathrm{Fe}$ and $\mathrm{Mn}$ in the deposited particles were similar to the concentrations determined in fragments of the railway tracks. Furthermore, a significant and relatively high correlation was observed between $\mathrm{Fe}$ and $\mathrm{Mn}$ (Table 2). Although the two heavy metals are also naturally found together in minerals (Emsley, 2001), we nonetheless believe that high concentrations of $\mathrm{Fe}$ and $\mathrm{Mn}$ in the brown section and outside Kongresna Dvorana resulted from train operation. Mixed sources could thus be assumed for Fe and Mn. They could be mostly of natural origin, but in several parts of the cave anthropogenic origin also seems to be relevant.

\section{Sprinkling sand}

A comparison of heavy metal concentrations in the fresh sprinkling sand, whose function is to obtain a better adhesion of the train wheels to the railway track, and the sand that was collected beside the railway track showed that concentrations of several heavy metals were significantly higher in the latter fraction. An approximately twofold increase in concentrations of $\mathrm{Al}$ and Fe for example was observed in the sand collected beside the railway track, while in the case of $\mathrm{Mn}$ the concentration was up to four times higher (Fig. 3). Mn concentration was nevertheless one and two orders of magnitudes lower than $\mathrm{Al}$ and $\mathrm{Fe}$, respectively. Frequent train rides into and out of the cave cause wear of the railway tracks over time. Therefore, the sprinkling sand is likely to be mixed with the constituents of the railway tracks as they wear and/or corrode. This explains the relative enrichment of heavy metals in the sand collected beside the railway tracks. However, the sprinkling sand may also act as an abrasive, grinding tiny particles containing metals from the railway tracks. Nevertheless, the only mineral present in the fresh sprinkling sand (Fig. 4), calcite, is softer than steel, thus negating the role of sprinkling sand as an abrasive. Although $\mathrm{Cr}$ was also determined in the railway tracks, no enrichment was observed in the sand collected beside the railway tracks. This can be explained by the fact that $\mathrm{Cr}$ usually clings to the steel layer and is not transferred elsewhere (Askeland et al., 2011).

Sprinkling sand is ground into fine particles due to the weight of the train and could be transported away from the railway tracks along the cave. Nevertheless, it seems that fine sand particles are still too large and/ or too heavy to be transferred away from the railway tracks. Fe and Al concentrations in the deposited particles were approximately one order of magnitude higher than in the fresh sprinkling sand (Figs. 2 and 3). If fine sand particles had been the major source of the particles deposited on the walls, then the concentrations of $\mathrm{Fe}$ and $\mathrm{Al}$ in the deposited particles should have been much lower. Furthermore, Sr was found in increased quantities in the sprinkling sand (Fig. 3). In all parts of the cave except at sampling sites 3.3A and 3.3B, Sr concentration in the deposited particles was at least two times lower than in the sprinkling sand (Table1, Fig. 2). This again supports our conclusion that sprinkling sand is not a relevant source of particles in the cave.

\section{Natural origin}

Al concentration in fragments of the railway tracks was one to two orders of magnitude lower than the concentrations observed throughout the cave. It therefore seems that other, probably natural sources are more important for Al, especially as Al is the third most abundant element in the Earth's crust with concentrations of up to $82,000 \mu \mathrm{g} \mathrm{g}^{-1}$ (Emsley, 2001). The very low correlation between $\mathrm{Al}$ and Fe (Table 2) could indicate that their sources are different. On the other hand, Al was significantly correlated with Mn. By comparing the distribution of the two heavy metals throughout the cave, we found that both distributions were remarkably similar, with the only exception observed in the brown section (Table 1, Fig. 2). At sampling site 4.1 , Mn concentration was among the highest and was attributed to train operation, while Al concentration was among the lowest observed in the cave. Since we assumed mixed sources for Mn, we concluded that natural sources could prevail for Al.

In most parts of the cave, Sr concentration was rather low, with almost no variations. Furthermore, concentrations lower than the common concentration in the Earth's crust (370 $\mu \mathrm{g} \mathrm{g}^{-1}$; Emsley, 2001) were mostly observed. Sr is one of the trace elements that can be found in limestone. It readily substitutes for $\mathrm{Ca}$ in carbonates and the concentration range observed in Postojnska jama corresponds to concentrations commonly observed in ancient limestone, i.e. from a few hundred to 2,000 $\mu \mathrm{g} \mathrm{g}^{-1}$ (Tucker \& Wright, 1999), thus suggesting a natural origin. There was, however, a significant increase in $\mathrm{Sr}$ in the upper part of Kongresna Dvorana, with concentrations that were much higher than in the other parts of the cave. We could only speculate that $\mathrm{Sr}$ at sampling sites 3.3A and $3.3 \mathrm{~B}$ might be of anthropogenic origin. $\mathrm{Sr}$ is frequently used as a constituent in pyrotechnics and in the production of flares (Daintith, 2004). The latter use in particular may have some effect, since flares were frequently used for illumination at events held in Kongresna Dvorana.

Cr exhibited the lowest concentrations obtained in this study. They were similar to the concentrations commonly found in the environment, i.e. around 100 $\mu \mathrm{g} \mathrm{g}^{-1}$ (Emsley, 2001) and we could thus conclude that sources of $\mathrm{Cr}$ are most probably natural.

\section{CONCLUSIONS}

Tourist facilities in Postojnska jama result in an evident anthropogenic impact on the cave. The distribution and composition of heavy metals in dust particles throughout the cave indicate that several sources could exist for the particles. Some particles seem to be of natural origin, but anthropogenic sources 
are also likely and important for some parts of the cave. The railway itself, as well as wear and/or corrosion of the railway tracks seem to be the most important anthropogenic sources of the deposited particles in the cave, while the use of sprinkling sand for a better adhesion of the train wheels is probably of negligible importance. Furthermore, specific characteristics of Postojnska jama, such as multiple entrances/ openings at different elevation and temperature differences between the cave and the ambient air enable more intensive particle transportation along the cave, above all in winter. This seems to be one of the most important factors regarding dust deposits, since literally no dust was observed in side passages with no air currents.

Dust deposits that darken the cave walls and flowstone can thus be attributed to the infrastructure in the cave. The deposits deteriorate the natural appearance of the cave and diminish its value as a show cave. The most serious issue, however, is that the deposits may also have a negative impact on cave fauna, since several heavy metals were observed in the particles in concentration levels that are much higher than their natural abundance. This aspect is of particular importance and should be included in future research. Finally, transportation of the particles along the main passage in the cave could, in our opinion, be substantially diminished by employing such simple measures as closing the entrance doors during winter (e.g., Garcia-Anton et al., 2012), in this way diminishing/disabling the supply of cold ambient air into the cave that subsequently impels air currents. The importance of draughts through a cave on the abundance and distribution of particles was also pointed out by Grgić et al. (pers. comm.). They recently studied the concentration of the particles in the cave air of the nearby Škocjanske jame (Škocjan Cave) and found that at times when the entrance door was opened for visitors, significantly higher concentrations of smaller size particles were observed in the cave air than at times when the entrance door was closed.

\section{ACKNOWLEDGEMENTS}

The authors would like to thank J. Burger, I. Kranjc, and S. Šerjak (Slovenian Environment Agency) for their valuable help in the laboratory. Dr. A. Šmuc (Department of Geology, University of Ljubljana) is kindly acknowledged for performing the X-ray diffraction analysis of the fresh sprinkling sand. Dr. Jonathan Dredge and two anonymous reviewers are acknowledged for their helpful suggestions and comments. The authors declare that they have no competing financial interests.

\section{REFERENCES}

Askeland D.R., Fulay P.P. \& Wright W.J., 2011 The Science and Engineering of Materials. Cengage Learning, Stamford.

Badino G., 1995 - Underground climate physics. Memorie dell'istituto italiano di speleologia, 7, serie II, Bologna (in Italian with English abstract).
Bruinen de Bruin Y., Koistinen K., Yli-Tuomi T., Kephalopoulos S. \& Jauntunen M., 2006 - Source apportionment techniques and marker substances available for identification of personal exposure, indoor and outdoor sources of chemicals. EUR 22349 EN Report, EC DG JRC, Luxembourg.

Christoforou C.S., Salmon L.G. \& Cass G.R., 1996 - Air exchange within the Buddhist Cave Temples at Yungang, China. Atmospheric Environment, 30: 3995-4006. http://dx.doi.org/10.1016/1352-2310(96)00123-9

Cuculić V., Cukrov N., Kwokal Ž. \& Mlakar M., 2011 - Distribution of trace metals in anchialine caves of Adriatic Sea, Croatia. Estuarine Coastal and Shelf Science, 95: 253-263. http://dx.doi.org/10.1016/j.ecss.2011.09.011

Čuk A., 2003 - Development of the underground railway system on the example of Postojnska jama. Acta Carsologica, 32: 225-242.

Daintith J., 2004 - The Facts on File Dictionary of Inorganic Chemistry. Facts on File, New York.

de Freitas C.R., 2010 - The role and importance of cave microclimate in the sustainable use and management of show caves. Acta Carsologica, 39: 477-489.

Dongarra G., Manno E., Varrica D., Lombardo M. \& Vultaggio M., 2010 - Study on ambient concentrations of $P M_{10}, P M_{10-2.5}, P M_{2.5}$ and gaseous pollutants. Trace elements and chemical speciation of atmospheric particulates. Atmospheric Environment, 44: 5244-5257. http://dx.doi.org/10.1016/j.atmosenv.2010.08.041

Dredge J., Fairchild I.J., Harrison R.M., FernandezCortes A., Sanchez-Moral S., Jurado V., Gunn J., Smith A., Spötl C., Mattey D., Wynn P.M. \& Grassineau N., 2013 - Cave aerosols: distribution and contribution to speleothem geochemistry. Quaternary Science Reviews, 63: 23-41. http://dx.doi.org/10.1016/j.quascirev.2012.11.016

Emsley J., 2001 - Nature's Building Blocks: an A-Z Guide to the Elements. Oxford University Press, New York.

EN 14902, 2005 - Ambient air quality. Standard method for the measurement of $\mathrm{Pb}, \mathrm{Cd}, \mathrm{Aa}$, and $\mathrm{Ni}$ in the $\mathrm{PM}$ 10 fraction of suspended particulate matter. European Committee for Standardization, Brussels.

EN ISO 17294-2, 2005 - Water quality - Application of inductively coupled plasma mass spectrometry (ICPMS) - Part 2: Determination of 62 elements. European Committee for Standardization, Brussels.

Faimon J., Štelcl J., Komberec M. \& Veselá P., 2011 Cave aerosol in Císařská and Sloup-Šošůvka Caves (Moravian Karst, Czech Republic). Slovenský kras (Acta Carsologica Slovaca), 49: 107-113.

Gabrovšek F. \& Mihevc A., 2009 - 17th International Karstological School "Classical Karst" - Cave Climate. Karst Research Institute ZRC SAZU, Postojna.

Gams I., 2003 - Karst in Slovenia in space and time. ZRC Publishing, Ljubljana, (in Slovenian, English summary). Garcia-Anton E., Cuezva S., Fernandez-Cortes A., Sanchez-Moral S. \& Canaveras J.C., 2012 - Multiparametric surveillance of conservation measures at subterranean rock-art site: case of Altamira cave. Geophysical Research Abstracts, 14 EGU2012: 831.

Goldberg E.D., 1985 - Black carbon in the environment. John Wiley \& Sons, New York.

Gregorič A., Zidanšek A. \& Vaupotič J., 2011 Dependence of radon levels in Postojna Cave on outside air temperature. Natural Hazards and Earth System Sciences, 11: 1523-1528. http://dx.doi.org/10.5194/nhess-11-1523-2011 
Gutiérrez M., Neill H. \& Grand R.V., 2004 Metals in sediments of springs and cave streams as environmental indicators in karst areas. Environmental Geology, 46: 1079-1085. http://dx.doi.org/10.1007/s00254-004-1110-4

Hester R.E. \& Harrison R.M., 1997 - Contaminated land and its reclamation. Royal Society of Chemistry, Cambridge.

Hrovatin N., 2006 - Tourism impact and tourism flows in Postojna Cave. Diploma Thesis, University of Primorska (in Slovenian with English abstract).

Kertész Zs., Borbély-Kiss I. \& Hunyadi I., 1999 - Study of aerosols collected in a speleotherapeutic cave situated below Budapest, Hungary. Nuclear Instruments and Methods in Physics Research Section B: Beam Interactions with Materials and Atoms, 150: 384-391. http://dx.doi.org/10.1016/S0168-583X(98)00899-4

Luetscher M. \& Jeannin P-Y., 2004 - Temperature distribution in karst systems: the role of air and water fluxes. Terra Nova, 16: 344-350.

http://dx.doi.org/10.1111/j.1365-3121.2004.00572.x

Mulec J., Vaupotič J. \& Walochnik J., 2012 - Prokaryotic and eukaryotic airborne microorganisms as tracers of microclimatic changes in the underground (Postojna Cave, Slovenia). Microbial Ecology, 64: 654-667. http://dx.doi.org/10.1007/s00248-012-0059-1

Pashchenko A., Dublyansky Y. \& Andreichuk V., 1993 Aerosol study in the Kungur Ice Cave (Urals, Russia). In: Proceedings 11th International Congress of Speleology, Beijing: 190-192.
Russell M.J. \& MacLean V.L., 2008 - Management issues in a Tasmanian tourist cave: Potential microclimatic impacts of cave modifications. Journal of Environmental Management, 87: 474-483. http://dx.doi.org/10.1016/j.jenvman.2007.01.012

Sket B., 2003 - Postojna - Planina cave system: biospeleology. In: Gunn J. (Ed.) - Encyclopedia of caves and karst science. Taylor \& Francis, London: 603-604.

Šebela S. \& Turk J., 2011 - Local characteristics of Postojna Cave climate, air temperature and pressure monitoring. Theoretical and Applied Climatology, 105: 371-386. http://dx.doi.org/10.1007/s00704-011-0397-9

Tucker M.E. \& Wright V.P., 1999 - Carbonate sedimentology. Blackwell Science, Oxford.

Vokal B., Obelić B., Genty D. \& Kobal I., 1999 - Chemistry measurements of dripping water in Postojna Cave. Acta Carsologica, 28: 305-321.

Watson J., Hamilton-Smith E., Gilleson D., Kiernan K. (Eds.), 1997 - Guidelines for cave and karst protection. IUCN, Gland.

White W.B. \& Culver D.C. (Eds.), 2012 - Encyclopedia of caves. Academic Press, Amsterdam: 618-624.

Zhou H., Greig A., You C-F., Lai Z., Tang J., Guan Y. \& Yuan D., 2011 - Arsenic in a speleothem from Central China: Stadial-interstadial variations and implications. Environmental Science and Technology, 45: 12781283. http://dx.doi.org/10.1021/es 1032103

Zupančič N., Šebela S. \& Miler M., 2011 - Mineralogical and chemical characteristics in black coatings in Postojna Cave system. Acta Carsologica, 40: 307-317. 